\title{
RELIGIO-POLITICAL DISCOURSES IN DOCUMENTARY FILMS ON IRAQ PROMOTING PEACE OR CONFLICT
}

\author{
Abida Ashraf \\ Institute of Communication Studies \\ University of the Punjab \\ Email:abidaeijaz@gmail.com
}

\begin{abstract}
I $\mathrm{n}$ the information age, media has become an important tool to seek information for clarity but it is paradoxical. This study shows whether documentaries are projecting skepticism and sarcasm of Iraqi people due to volatile, uncertain complex, and ambiguous (VUCA) conditions or projecting VUCA discourses for the restoration of peace and harmony. The object of this study consists of Oscar-winning and Oscar-nominated documentary films from 2003 to 2011 with a total of 45 films. The year 2003 is selected for its demarcation of U.S.-led invasion of Iraq which started in March 2003 and toppled over the government of Saddam Hussein. The year 2011 denotes the end with the departure of US troops in 2011. Through the criterion sampling, four films are selected that depict Iraq and all the four got nomination for Oscar that include: Iraq in Fragments (2006-Nomination); My Country My Country (2006-N); No End in Sight (2007-N); Operation Homecoming: Writing the Wartime Experience (2007-N). To explore Iraqi people's perspectives, a further sampling is applied and two documentaries are selected depicting entanglement of religion and politics in Iraq from Iraqi people's perspective.
\end{abstract}

\section{Keywords: Discourse, Documentary Film, Peace Journalism, VUCA.}

\begin{abstract}
ABSTRAK
$\mathrm{D}$ i era informasi, media telah menjadi alat penting dalam mencari informasi untuk kejelasan tetapi itu paradoks. Studi ini menunjukkan apakah film dokumenter memproyeksikan skeptisisme dan sarkasme rakyat Irak karena kondisi yang tidak menentu, rumit, dan ambigu (VUCA) atau memproyeksikan wacana VUCA untuk pemulihan perdamaian dan harmoni. Objek penelitian ini terdiri dari film dokumenter yang memenangkan Oscar dan nominasi Oscar dari 2003 hingga 2011 dengan total 45 film. Tahun 2003 dipilih karena demarkasi atas invasi pimpinan-AS ke Irak yang dimulai pada Maret 2003 dan menggulingkan pemerintahan Saddam Hussein. Tahun 2011 menunjukkan akhir dengan kepergian pasukan AS pada 2011. Melalui sampling kriteria, empat film dipilih yang menggambarkan Irak dan keempatnya mendapatkan nominasi untuk Oscar yang meliputi: Irak dalam Fragments (2006-Nominasi); My Country My Country (2006-N); No End in Sight (2007$\mathrm{N})$; Operation Homecoming: Writing the Wartime Experience (2007-N). Untuk mengeksplorasi perspektif rakyat Irak, dilakukan sampling lebih lanjut dan dua film dokumenter dipilih yang menggambarkan keterikatan agama dan politik di Irak dari perspektif rakyat Irak.
\end{abstract}

Kata kunci: Wacana, Film Dokumenter, Jurnalisme Perdamaian, VUCA 


\section{INTRODUCTION}

Documentary films propose, challenge, promote, criticize, or reinforce arguments through modes. Pramaggiore and Wallis writem said, "Documentary filmmakers employ a number of rhetorical strategies to support their assertions about the world" (2005: 286). This paper evaluates filmmakers' assertions on the one hand and analyzes films' contribution in promoting peace or conflict.

The two Oscar-nominated documentary films selected for this study include: "Iraq in Fragments", and "My Country, My Country". Oscar awards are acclaimed to be prestigious at global level and the discourses highlighted in Oscar-winning and Oscarnominated films get attention and fame. According to Van Dijk discourses set frames for meaning and practice, "...At the global level of discourse, topics may influence what people see as the most important information of text or talk, and thus correspond to the top levels of their mental models" (2007: 358).

'Iraq in Fragments' is a part of the "Iraq Media Action Project" for film collection, directed by James Longley, and nominated for an Oscar award for the category of Best Documentary Feature Film in 2006. Viewpoint of James Longley, the filmmaker, reflects through scene selections, frames, light and sound. The film presents a kaleidoscopic view of life in Iraq. The film comprises of fifteen chapters divided into three parts: Sunni Arabs in Baghdad; radical Shia Mahdi Army militia Moqtada al-Sadr; and Kurds in the north of Iraq. The film is more expressionistic as there is no 'Voice of Authority' mode used in the film. Video footage in 'Direct Cinema' mode and 'Talking Heads' mode are applied throughout the film. The title of the film is quite suggestive, referring to political, ideological, and cultural fragmentations in Iraq. The film brings forth Iraqi people's perspectives on the US occupation of Iraq and its repercussions.

Laura Poitras is the producer and cinematographer of the film 'My Country, My Country'. Laura spent eight months in Iraq to get footage for her documentary. She met Dr. Riyadh, an Iraqi medical doctor, at Abu Gharib prison during his inspection. Laura decided to capture his story in the perspective of January 2005 elections after U.S. occupation. Dr. Riyadh is a Sunni Muslim political candidate, who is an outspoken critic of U.S. occupation. The will of an occupied population is depicted through the public interviews and daily interactions of Dr. Riyadh. The film reveals the implications of U.S. project to implement democracy in the Middle East, with the help of Australian private security contractors, American journalists and UN officials. The film consists of twelve chapters and delivers an insider's perspective about the use of U.S. preemptive military force after $9 / 11$ for the implementation of democracy in the Middle East. Both the films provide an insight to the use of U.S. preemptive military force and its consequences. 'My Country, My Country' is an Oscar-nominated documentary film of 2006 produced by Laura Poitras, an American. The film depicts Iraqi elections from the perspective of an Iraqi medical doctor named Riyadh. The film highlights the religious circumstances and political situation through the main participants of the film Dr. Riyadh, who is a Sunni Muslim, a candid critic of U.S. occupation, and a political candidate of the elections of 2005. $\mathrm{He}$ is an Iraqi medical doctor who also served at Abu Gharib prison. Miseries of common people are uncovered through Dr. 
Riyadh which suggests filmmaker's preference of 'peace journalism'.

\section{METHODOLOGY}

The study analyses religio-political discourses through quantitative and qualitative approaches against the backdrop of Galtung's 'Peace Journalism Model' which suggests how journalists can transform conflict by peaceful means (2002: 259-272). The films under study have been evaluated for four categories of peace journalism model which include; peace oriented; truth oriented; people oriented; and solution oriented discourse as compared to war journalism which focuses on war oriented; propaganda oriented; elite oriented; and victory oriented discourse. Each chapter of the film is selected as a unit of analysis constituting twenty seven chapters altogether. For quantitative analysis, a coding frame of three dimensions is adapted from Diana Ross's study on moving images to analyze narrative structure (2003: 246-262). The coding frame includes: diegetic sound vs. non-diegetic sound; mode type which includes voice of authority (VoA), talking heads ( $\mathrm{TH})$, direct cinema (DC), and reflexive mode, and dialogue time. For qualitative analysis, all the twenty seven chapters are evaluated against the model of peace journalism for above-mentioned four categories.

\section{THEORY: GALTUNG'S PEACE JOURNALISM PERSPECTIVE}

The idea of peace journalism refers to journalists' deliberate choices to cover and report conflicts in a way that ultimately contributes to non-violent responses and peaceful outcomes to conflicts. Peace journalists consider themselves as part of the solution and not part of the problem. This self-orientation transforms the whole paradigm of conflict reporting. The idea of peace journalism comes from Galtung and Ruge's research on the structure of foreign news in which they have critically evaluated news values and rejected the idea of 'violence' as news value in reporting. Peace journalism is also perceived as good journalism or ethical journalism (1965: 6490). While expanding Galtung's concept of peace journalism, Lynch and McGoldrick (2005) explain it as health journalism. A good health correspondent would describe a patient's battle against cancerous cells eating away at the body.

From Galtung's peace journalism perspective, the film promotes the discourses of peace by highlighting the perceptions and perspectives of common people, projecting multiple realities and truths, voicing unheard voices, elucidation context of the conflict, and suggesting solutions proposed by general public instead of highlighting elite's perspective, projecting conflict between two parties, promoting victory oriented discourse through 'othering', demonizing and dehumanizing one party, suggesting solutions proposed by top-level (2002: 259272).

Peace journalism model has been applied on reporting of conflicts in the media. Documentary film is also considered as a news genre therefore, peace journalism model is applicable on documentary films. The films under study are evaluated for the four dimensions of peace journalism model which include peace, truth, people, and solution frames as compared to war journalism model that focuses on war, propaganda, elite, and victory frames. Both the films, Iraq in Fragments and My Country, My Country are evaluated for promoting peace or war discourses. 

belonging to different segments of

\section{RESULTS AND DISCUSSION}

\section{A. War/Peace Oriented Discourse:}

War oriented discourse focuses on two parties i.e. self and other or us vs. them, with one goal, as compared to peace oriented discourse that covers multiple parties/groups, with many goals. Peace oriented discourse means digging deep, reporting context, exploring different dimensions, naming evil on all sides. Both the films are evaluated against war/peace oriented discourse.

Iraq in Fragments: The film shares context of factionalism that is dividing Iraqis. General Maude during WWI, took Baghdad and tried to promote factionalism. The plan could not succeed as Shia and Sunni were united at that time but the situation is different now. Shiites perceived Saddam in a different perspective, as a blasphemer who imposed sanctions on flagellations and other Islamic customs and traditions. They believe that Saddam was scared of Shia to be the most revolutionary of all Muslims hence could topple over his government. A cleric is shown claiming, "Saddam knows that the Shia is the most revolutionary of all Muslims." Therefore he victimized Shia population in Iraq. As a reaction, Dawah, the Shiites political party, conferred more jobs to their workers on the basis of sectarianism. Direct cinema mode scenes about Shia and Sunni Iraqis are juxtaposed to show the attitudes of Shia and Sunni Iraqis towards their community. However, the two other important characters, Mohammad and his boss both are Sunnis but Mohammad is exploited by his boss. The film depicts how sectarianism in Iraq is contributing to its instability and VUCA conditions.

Perspectives and views of Iraqis population are depicted in the documentary. Sheikh Aws, a religious scholar and a leader has been filmed, saying in a public address that America is befooling them by secretly supporting Israel while claiming that she is helping Iraq. Because of this hypocrisy, Sheikh Aws declares the fight against America as a Jihad (holy war) in which faithful believers fighting against America are glorified and those who support America are considered as spies who will meet a grievous end. Contrary to this view, one of the main participants from Kurdistan, Mahmoud, believes that suicide bombing is not Jihad. In a hospital of Sadr, a victim of the bombings comments that hundreds of Saddam have been produced to replace the system. America views this scenario as extremism while Southern Iraqis consider it as their right of self-defense.

My Country, My Country: The film shows that how people's sympathies are divided on the basis of their sects. Media gives coverage to political turmoil in Fallujah and killings of Sunni people during Friday prayer to depict sectarian factor in the politics of Iraq. Baghdad with dominant Sunni population, extends full support and sympathize with Sunni Fallujah people.

During a military training, an American military official advises his people to be careful because of the anit-American sentiment among Iraqis. In Kurdistan security contractors are engaged in getting latest weapons for security purposes like AK47 gun, manufactured in China and Russia. Weapons are considered to be imported for security but the outcome is increased killings of innocent people. Iraqi people are being killed every day just for oil politics.

Both the films are depicting the casualties, sufferings and victimization of 
innocent people which shows filmmakers' preference of peace journalism over war journalism.

\section{B. Propaganda/Truth}

Oriented

\section{Discourse:}

Peace journalism aims to uncover hidden realities, providing facts with responsibility, imagining consequences and future repercussions of reporting. While propaganda discourse contributes to war journalism by exaggerating realities, focusing selective dimensions of the conflicts to manipulate perceptions. Objectivity does not appear to be the ultimate goal of the peace journalism if it contributes to the conflict escalation.

Iraq in Fragments: The film highlights different viewpoints of Iraqi people about American interference in their country. Some Iraqis think that America forcefully entered in Iraq as a liberator and became occupier and others think that America turned against Saddam after supporting him for a period of thirty five years. "America promised a life of comfort, freedom, democracy. But we knew it was all lies." These are the dialogues from the last chapter of part II, (DVD version) titled as 'Who Can Trust America'. Iraqi people feel that they have been cheated and betrayed at the hands of America. A religious scholar Sheikh Aws says, "America is plundering wealth and wants to control the minds." The statement shows that Iraqi people are quite aware of their VUCA conditions and hidden agenda of oil politics.

Mohammad from Baghdad, believes that America has disrupted the peace of Baghdad for oil politics. In a discussion with his boss, Mohammad considers Saddam Hussain a better ruler as America has brought much higher level of destruction as compared to thirty five years rule of Saddam. Mohammad's father, who was a police officer, disappeared and nobody knew his whereabouts. A brother and a sister of Mohammad's boss was killed by Americans for not stopping on their orders. Mohammad comments on the investigation carried out for Saddam and telecasted on television showing police officers searching his mouth, beard, and teeth which is quite funny. Saddam is shown on television with a sword in his hand depicting him a brutal person. The north Iraq that comprises Kurds have a different view. They consider America as an opportunist who tried to make the most of the Iraq's situation and view Saddam as an oppressor.

The film shows that Iraqis do not want American brand of democracy. Sheikh Aws, a religious scholar's views on US presence in Iraq are depicted while he is addressing to Muslims gathered for prayers, "They came to teach us of western democracy, killing, displacement, and torture, arrests without charge in the land of Iraq. This is the democracy they have brought." Iraqis believe that America wants bombings and killing innocent people in the pretext of peace and democracy. Therefore, the selfimaginations of Iraqis are transforming into, "It's impossible to change us with the barrel of a tank." An injured activist at a hospital shows his reservations on the American brand of democracy as hundreds of Saddams are being produced to replace the system. Mohammad says America is interested in oil therefore wants to have a new president of their choice to implement her oil plans. However, Kurds have a different view and believe in the power of vote. One of the Imam from Kurdistan says, "The vote that you will cast is better than 100 bombs and 200 boxes of bullets." The statement shows Kurds conviction in democracy and 
Religio-Political Discourses In Documentary...hal 121-132

elections but they do not support American activities. The main character Mahmoud tells, "Today, everything in Iraq is controlled by America. Nobody can escape America's reach. America is victimizing Muslims throughout the world in the name of democracy and peace."

My Country, My Country: U.S. Assistant Secretary of State Richard Armitage along with other U.S. officials are engaged to make elections a success and to change the face of Middle East. Kurdish people are shown as grateful to Bush government and U.S. for liberating them from Saddam. They consider Saddam as a cruel dictator who has victimized 25 million people of all ethnicities and religions including Arabs, Turkmans. Kurds, Sunni, Shia, and Christians. However Iraqis believe that America is not interested in transforming Iraq into a social welfare state but only concerned to conduct elections. There is an anti-American sentiment and antagonism among Iraqis therefore the security contractor, Peter decides not to wear uniform but simple clothing during elections.

The film depicts Baghdad for American dream of democracy but situation deteriorates day by day as killings, bombing, shooting, and riots are at increase before the elections of 2005. Basic human rights are not available as there is no water, no electricity, and no security in Baghdad. Dr. Riyadh wants elections to be successful therefore, he gets busy in convincing people not to boycott elections and should fully participate in election activities. Another discourse about elections is depicted as, “...if one person's freedom, one person's dignity is being abused, such elections should be stopped. The whole nation should stand on its feet and stop the elections."

Both the films highlight ostracized realities, challenge propaganda, and promote truth by projecting contrapuntal texts.

\section{Elite/People Oriented Discourse:}

Peace journalism means promoting people oriented discourse. Iraqi mainstream media along with the international media contributed to both peace and conflict discourses through television reports, radio news relays and other information sources that contributed to VUCA conditions in Iraq.

Iraq in Fragments: Iraqi mainstream media contributed to VUCA through television reports, and radio news relays for example, a radio news relay informs about torturing of Iraqi detainees at Abu Garib prison and demands to publicize each and every detail of detainees that shows a watchdog role of media. Chunks from television reports show that Iraqis motivation is 'Vietnam' because they have successfully expelled America. News items telecasted via television are treated and framed in a way that apparently support Iraqis and give the impression of watchdog role. Some media reports critically evaluate America's claim to be a liberator in the guise of an occupier. America believes in the use of force and is engaged in killing innocent people in the name of peace and democracy.

One of the scenes depicts Shiite in Sadr listening to the sermon of a young child reviving the spirit of freedom and hope through his sermon. He says, "We will rise up like a great earthquake, be gone oppression and torture of Saddam." Shiites are shown preparing for elections under 'Sadr Movement' with a hope to bring peace and betterment. Other Shiite scholars do believe that Iraq's democratic and Islamic movements can serve as a source to liberate Iraq through secret balloting in general 
elections.

In part three Mahmood exquisitely narrates the story of two wrestlers, where someone asks whose side is God on and the reply is, God is always on the side of the winner. It is the commitment, effort and level of struggle that determines who is going to be the winner. If Iraqis are determined to restore peace and get freedom, they have to synergize and stand united for their cause.

My Country, My Country: A television newsreel mentions an incident 6 weeks before elections, "This morning during rush hour four election workers were dragged from their cars and executed." Fox TV shares a news story about elections boycott by a top Sunni candidate. Two bomb blasts, blocked roads, kidnapping incidents, election boycott is reported on election day but another TV newsreel shows American president George W. Bush congratulating Iraqi people for holding successful elections.

Iraqi Islamic Party boycotts elections by saying that, "The persistence violence will stop people from voting in the north and west of the country where Sunnis are concentrated". The statement shows VUCA conditions of Iraq. There is another perspective that if elections fail, the situation may lead to chaos in the entire region. However, there is another apprehension that Americans will be justified to do the same experiment in the entire Middle East if elections prove a success. 58\% Iraqis casted their vote and majority Sunni boycotted the elections. The environment of fear, threat, insecurity as well as hope prevails even after elections.

\section{Victory/Solution Oriented Discourse:}

Peace journalism means reporting in a

way as to find solutions suggested by all stakeholders existing at multiple levels. Winning or losing is not the focus rather the focus is to incorporate suggestions of almost all stakeholders, and finding solutions which is not a compromise but based on an inclusive approach for positive and sustainable peace.

Iraq in Fragments: The opening scenes show beautiful and peaceful Baghdad transforming into war stricken Baghdad. A Sunni Arab boy Mohammad, an orphan, is shown working for his cruel and abusive boss in his auto workshop after the US attack on Iraq which symbolizes the two countries as well; Iraq and America. Mohammad does not get any salary from his boss says, "I worked and dreamed. Now I kept working and stopped dreaming." Discussions between the boss and Mohammad suggest that rich are always beneficiaries in any circumstances while poor are the ultimate victims in case of any miseries. However, the solution to the prevailing miseries of Muslims is suggested in unity.

Scenes of Mohammad's school show teachers motivating students to work hard and concentrate on their studies so that they can fight against imperialist forces and bring reforms in Iraq. Religious education is also being imparted in school. However the later scenes propose that practicing Muslims are unfair and dishonest. As Mohammad's boss says, "But one who prays and calls himself a God-fearing man, in matters of work or money he will always screw you." $\mathrm{He}$ further maintains that if one treats well with drunken and evil-doers, they will be transformed and contribute more positively in the society. Scenes sequence and arrangement shows that religious education cannot bring good change and materialize Iraqi dreams.

The scenes from 'Sadr' promote the 
Religio-Political Discourses In Documentary...hal 121-132

discourse that people want Americans to leave their country as American forces have beaten their Imams and trampled their holy places. However, Kurds have different perspective on being religious or secular. They believe that religion dominates thinking and practice of Kurds as people offer prayers regularly and take care of their old parents.

Mohammad wants to escape from Iraq in search of peace and safety in the outer world. He dreams of becoming a pilot so that he can explore peaceful and beautiful countries. The film shows that Mohammad is divided in school and work. Education system in Iraq is not facilitating poor as Mohammad cannot write even his father's name after spending four years in school. He is obliged to choose work and compromise his dreams. There is a conflict going on within Mohammad as he says, "In my uncle's shop nobody beats me, nobody swears at me and I feel relaxed" which is contrary to the reality. In part one of the film, Arabs are depicted as ill-mannered, uneducated, and oppressors while part three shows Kurds as peaceful, hardworking and democratic people.

My Country, My Country: The VUCA conditions continue to prevail even after the elections. On the very next day of elections, television report shows gunship helicopters patrolling. It is shared that 100,000 people have died of war-related causes since American occupation. Overall film proposes Middle East culture is quite different from

"Our religious and wise scholars agree that it is necessary to push back and resist an enemy who tries to take over a Muslim country. The question is, can we achieve this by participating in these elections or not?" The film shares that after the American occupation, 100,000 people have died of war-related problems.
American culture therefore, Iraqi people should solve their problems themselves. In some scenes, Iraqis are shown to be incapable of conducting elections and running democracy. The film criticizes the act of installing democracy as it cannot help Iraqis.

Dr. Riyadh considers religion to be an integral part of the government. In the context of his work experience at $\mathrm{Abu}$ Gharib prison, he believes that a secular government is more likely to promote chaos and uncertainty. According to Dr. Riyadh, "Denying your religion is like denying your identity...your country. Secularism won't give us our rights. America is secular but its democracy hasn't achieved justice... All religions preach justice. They don't call for people to occupy, kill, rape, or marginalize others." The films shows that Kurds are against Arabs and think that Saddam has taught them how to mutilate bodies, cut the tongues, electrocute and behead people.

Dr. Riyadh runs a free medical clinic and gets to know people's perceptions about U.S. invasion. When shootings in Fallujah followed by explosion in Adhamiya, Dr. Riyadh's family thought that Dr. Riyadh's services are more required to save people's lives instead of becoming a politician. However, he is convinced that Iraqis should participate in elections as a religious duty and a moral obligation.

Iraqis should get maximum representation in the parliament for the betterment of Iraq. Another candidate says,

The documentaries show how intermingling of religion and politics is resulting in the division of Iraq in fragments. Overall the discourses suggest that increased skepticism and polarization in political and religious domains offer two possibilities: an increase in the confused and split identities sustaining VUCA conditions; a realization 


\section{Abida Ashraf}

of beauty in diversity and recognition of pluralism to achieve integrity under a visionary and true leadership.

The production processes of the documentary films (text) depict discursive practices while the outcome is the discourse. The following table and graphs show the treatment given to these documentary films by the filmmakers.

Table I

Non-Digetic Sound, Mode of Dialogue and Time

\begin{tabular}{ccc}
\hline \hline Films & $\begin{array}{c}\text { My Country, } \\
\text { My Country }\end{array}$ & Iraq in Fragments \\
\hline Year & $2006(\mathrm{~N})$ & $2006(\mathrm{~N})$ \\
Film Time & $1: 59: 42$ & $01: 30: 50$ \\
ND Sound Time & 14.52 & $43: 56$ \\
VOA (D) & 30 & Nil \\
TH (D) & 49 & 324 \\
DC (D) & 867 & 417 \\
Total (D) & 940 & 741 \\
Mode VOA (T) & $0: 02: 10$ & Nil \\
Mode TH (T) & $0: 3: 23$ & $05: 10$ \\
Mode DC (T) & $1: 49: 53$ & $1: 21: 10$ \\
\hline \hline
\end{tabular}


Religio-Political Discourses In Documentary...hal 121-132
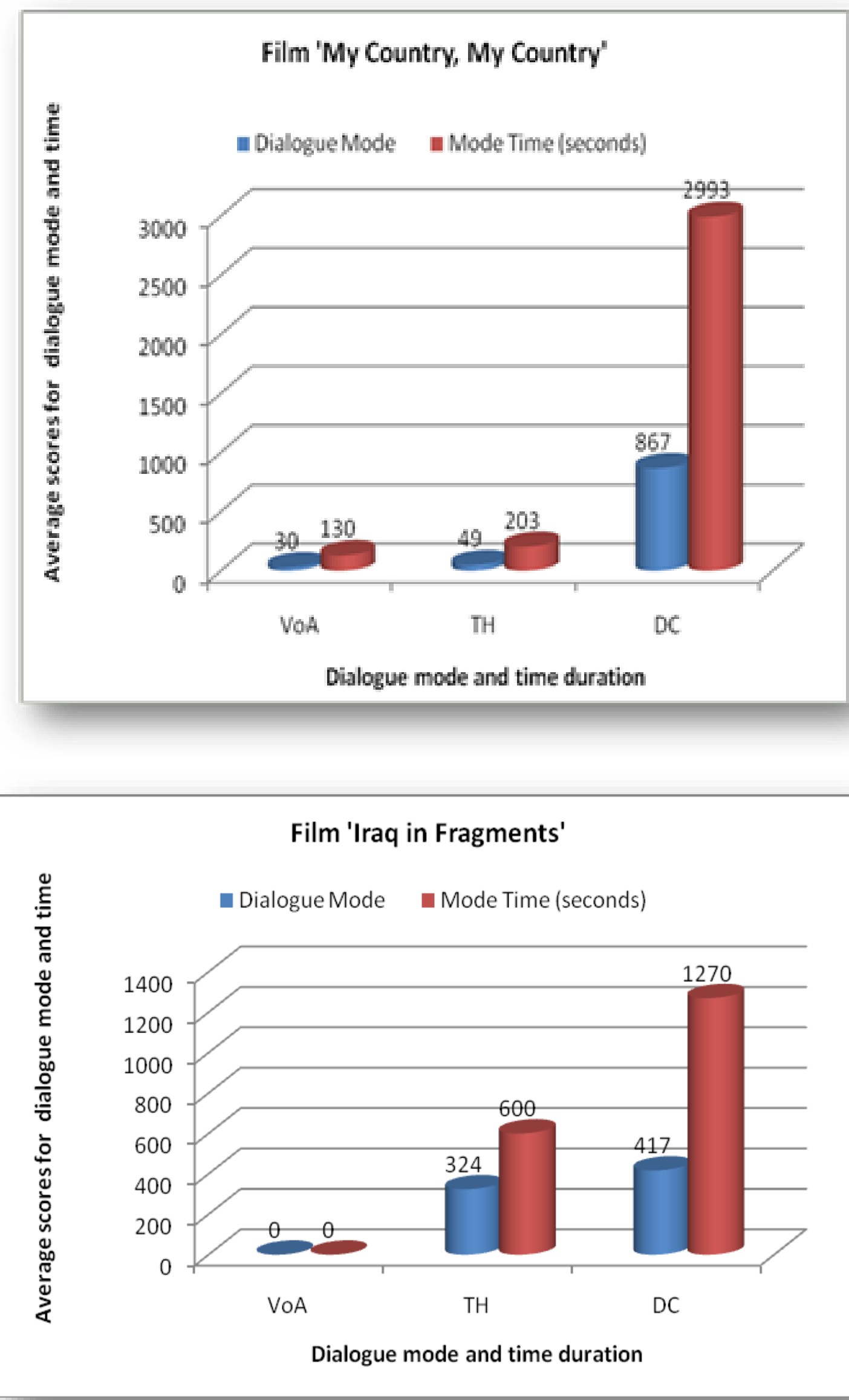

$130 \mid \begin{aligned} & \text { Islamic Communication Journal } \\ & \text { Volume 4, Nomor 2, Juli-Desember } 2019\end{aligned}$ 
Abida Ashraf

Fig. 2 Dialogue Mode and Mode Time of Iraq in

\section{Fragments}

The above table and graphs explain selection of modes that includes voice of authority (VoA), talking heads (TH), and direct cinema (DC) modes. Data shows time consumed for different modes (Eijaz, 2012). The mode selection and time consumed depict gatekeeping and framing. Gatekeeping and framing analysis complement each other to address the questions of 'what' and 'how' of the content. Laura Poitras, the filmmaker of My Country My Country has applied direct cinema mode for maximum time and on maximum dialogues. As a filmmaker, she is trying to be objective and neutral as the above graph shows.

In the documentary film Iraq in Fragments, James Longley has utmost applied direct cinema mode and totally ignored voice of authority mode that is making him less biased. According to Nicholas (1991), direct cinema mode restricts a filmmaker to control and manipulate narrative structures in certain manner, the application of direct cinema mode is appreciated. However, sequencing of scenes, juxtaposing, chapter titles, supportive non-diegetic sound facilitate the filmmaker in frame amplification and frame extension.

\section{CONCLUSION}

The findings conclude the following:

1. The documentaries show how politics in the backdrop of religion is intertwined and entangled owing to the internal and external factors.

2. The discourses in documentaries are not a mere reflection of reality, but a form of constructing reality with the aim to suit the needs of documentary film.

3. Overall the religio-political discourses suggest that increased skepticism and polarization on the one hand and self-reflections of the Iraqi people on the other hand offer two possibilities:

- An increase in the confused and split identities sustaining VUCA conditions;

- Or an awareness and recognition to diversity and pluralism promoting peace.

The findings suggest that both the films highlight VUCA conditions in Iraq. However, filmmakers preferred to select peace oriented, solution oriented, truth oriented, and people oriented frames instead of war oriented, victory oriented, propaganda oriented, and elite oriented frames. Owing to the application of former frames, the films are contributing the following: promoting empathy and humanization, sensitizing towards proactive approach for the prevention of violence, trying to uncover all cover-ups, giving voice to voiceless, giving name to all evil-doers, highlighting sufferings of all and sundry, bringing resolution and hope. The analyses also suggest that documentary filmmakers can serve as active agents of de-escalation and depolarization. Hence, documentary films can be a viable option for promoting peace journalism.

\section{REFERENCES}

Dijk, T. A. Van. 2001. "Critical Discourse Analysis, ” in D. Schiffrin, D. Tannen, H. E. Hamilton, (Eds.) The Handbook of Discourse Analysis (pp. 352-371). Blackwell Publishers. 
Religio-Political Discourses In Documentary...hal 121-132

Eijaz, A. 2012. "Depiction of Religions in Oscar-Winning and Osca-Nominated Documentary Films (1997-2006)", An Unpublished Ph.D thesis, University of the Punjab Lahore, Pakistan.

Galtung, J and M. H. Ruge (1965), "The Structure of Foreign News: The Presentation of The Congo, Cuba and Cyprus Crises in Four Norwegian Newspapers." Journal of peace research. Vol. 2, No. 1, pp. 64-90.

Galtung, J. 2002. "Peace journalism-A Challenge." Journalism and the New World Order, 2, pp. 259-272.

Lynch, J and A. McGoldrick. 2005. Peace journalism. Stroud: Hawthorn Press.

Nichols, B. 1991. Representing Reality: Issues and Concepts in Documentary (Vol. 681). Indiana University Press.

Pramaggiore, $\mathrm{M}$ and T. Wallis. 2005. Film: A Critical Introduction. Laurence King Publishing.

Rose, D. 2003. "Analysis of Moving Images.” In M. W. Bauer \& G. Gaskell (Eds.). Qualitative Researching with Text, Image and Sound: A Practical Handbook (pp. 246-262). London: Sage Publications. 